\title{
Overview of Mechanisms Involved During the Quenching and Partitioning Process in Steels
}

\begin{abstract}
M.J. SANTOFIMIA, L. ZHAO, and J. SIETSMA
The application of the quenching and partitioning $(\mathrm{Q} \& \mathrm{P})$ process in steels involves a microstructural evolution that is more complex than just the formation of martensite followed by carbon partitioning from martensite to austenite. Examples of this complexity are the formation of epitaxial ferrite during the first quenching step and the formation of bainite, carbides, and carbon gradients as well as migration of martensite/austenite interfaces during the partitioning step. In this work, recent investigations on the mechanisms controlling microstructural changes during the application of the Q\&P process are evaluated, leading to phase-formation based concepts for the design of Q\&P steels.
\end{abstract}

DOI: $10.1007 / \mathrm{s} 11661-011-0706-\mathrm{z}$

(C) The Author(s) 2011. This article is published with open access at Springerlink.com

\section{QUENCHING AND PARTITIONING PROCESS}

NEW strategies for the creation of advanced high strength steels with improved mechanical properties of strength, toughness, and ductility are based on the development of microstructures consisting of ultrafine phases formed in nonequilibrium conditions such as martensite and bainite in combination with retained austenite.$^{[1]}$ The refined and highly dislocated martensite and bainite contribute to a simultaneous increase of strength and toughness. Retained austenite contributes to the improvement of the strength/ductility combination via the transformation induced plasticity (TRIP) effect and to the improvement of the toughness if the retained-austenite grains have a filmlike morphology. One of the most innovative procedures to create microstructures consisting of martensite and retained austenite is the so-called quenching and partitioning (Q\&P) process. ${ }^{[2]}$ This process starts with a total or partial austenitization, followed by a quench of the microstructure to a temperature (quenching temperature) below the martensite start $\left(M_{S}\right)$ temperature but above the martensite finish $\left(M_{f}\right)$ temperature to form a controlled fraction of martensite. This microstructure is then subjected to a treatment at the same or higher temperature (partitioning temperature) in order to accomplish the carbon diffusion from the carbon-supersaturated martensite to the neighboring austenite. Finally, the material is quenched to room temperature and the austenite that has been sufficiently carbon enriched remains metastable at room temperature, whereas the rest transforms into martensite.

M.J. SANTOFIMIA, Postdoctoral Researcher, and L. ZHAO, Research Fellow, are with the Materials innovation institute (M2i), 2628 CD Delft, The Netherlands. Contact e-mail: m.j.santofimianavarro@ tudelft.nl J. SIETSMA, Professor, is with the Department of Materials Science and Engineering, Delft University of Technology, 2628 CD Delft, The Netherlands.

Manuscript submitted November 17, 2010.

Article published online April 26, 2011
Investigations on the $\mathrm{Q} \& \mathrm{P}$ process were mainly focused on the application of this heat treatment to steels with chemistries very close to commercial TRIP steels, ${ }^{[3-8]}$ designed to promote bainite formation, whereas studies on steels specially designed to be subjected to the Q\&P process are fewer. ${ }^{[-11]}$ Depending on the steel composition and the particular heat treatments, formation of bainite, ferrite, and carbides during the Q\&P process can overlap with carbon partitioning from martensite to austenite, reducing the effectiveness of this heat treatment leading to the desired microstructures. An adequate theoretical knowledge of the mechanisms occurring during the Q\&P process would lead to a well control of these overlapping phenomena. In the present work, recent investigations on the microstructural changes during the application of the Q\&P process in a variety of steel compositions are reviewed and discussed, leading to valuable information for the selection of alloying elements and heat treatment parameters in the design of Q\&P steels.

\section{MICROSTRUCTURAL CHANGES DURING AUSTENITIZATION AND COOLING}

The Q\&P process starts with full or partial austenitization. The selection of either initial step depends on the targeted mechanical properties. ${ }^{[12]}$ Steels processed by Q\&P starting with full austenitization can be generally considered for both bar and sheet steel applications, whereas steels processed by Q\&P starting with partial austenitization will contain a certain amount of ferrite in the microstructure and are mainly considered to be cold rolled for sheet applications. ${ }^{[12]}$ Adequate partial or full austenitization temperatures can be selected from the calculation of the characteristic ferrite/austenite transformation temperatures by means of physically based $\mathrm{d}^{[13,14]}$ and empirical models ${ }^{[15]}$ as well as from calculations based on thermodynamic databases, 
such as those included in commercial software MTData $^{[16]}$ and Thermo-Calc. ${ }^{*[17]}$

*Thermo-Calc is a trademark of Thermo-Calc, Stockholm.

The influence of the initial microstructure, i.e., prior to the application of the heat treatment, is especially important in the case of Q\&P treatments starting with partial austenitization. For example, Figure 1(a) shows the microstructure of an $0.2 \mathrm{C}-3.5 \mathrm{Mn}^{[1]} .5 \mathrm{Si}$ (wt pct) steel consisting of martensite and ferrite. ${ }^{[9]}$ Partial austenitization of this initial microstructure at $1043 \mathrm{~K}\left(770{ }^{\circ} \mathrm{C}\right)$ for 600 seconds followed by a quench at $50 \mathrm{~K} / \mathrm{s}$ led to a microstructure consisting of martensite and filmlike ferrite (Figure 1(b)). Figure 1(c) shows the microstructure obtained after partial austenitization, quenching to $513 \mathrm{~K}\left(240{ }^{\circ} \mathrm{C}\right)$, and partitioning at $623 \mathrm{~K}\left(350{ }^{\circ} \mathrm{C}\right)$ for 1000 seconds. The resulting microstructure contains filmlike ferrite obtained from the intercritical condition, together with martensite and a volume fraction of retained austenite equal to $0.18 .^{[9]}$ Preliminary analysis of the mechanical properties of these types of microstructures resulted in very promising levels of strength and ductility. ${ }^{[9]}$

The morphology obtained after partial austenitization in the previous example is quite different from the TRIP microstructure of an 0.19C-1.61 Mn-0.35Si-1.10Al-0.09P (wt pct) steel, formed by ferrite, bainite, and retained austenite, as shown in Figure 2. ${ }^{[4]}$ This microstructure was subsequently partially austenitized at $1173 \mathrm{~K}$ $\left(900{ }^{\circ} \mathrm{C}\right.$ ) for 600 seconds and cooled at $50 \mathrm{~K} / \mathrm{s}$ resulting in equiaxed ferrite and martensite (Figure 2(b)). In this image, it is possible to distinguish that ferrite undergoes two different etchings after application of LePera etching. ${ }^{[18]}$ Ferrite etched in dark blue was present at the intercritical temperature, whereas ferrite etched in light blue was formed during cooling by growth of intercritical ferrite. The latter ferrite is named epitaxial ferrite, and more information about its formation in this material can be found elsewhere. ${ }^{[4,19,20]}$ Some studies have shown that epitaxial ferrite beneficially affects the mechanical properties of dual-phase steels, ${ }^{[21-23]}$ so, in principle, it should not necessarily be avoided in the case of Q\&P steels, but be well controlled.

If the same material is fully austenitized at $1373 \mathrm{~K}$ $\left(1100{ }^{\circ} \mathrm{C}\right.$ ) for 300 seconds and cooled at $100 \mathrm{~K} / \mathrm{s}$, the resulting microstructure contains phases formed prior to the martensite formation such as Widmanstätten ferrite and lower bainite, as shown in Figure 3. The formation of such phases modifies the morphology and volume fraction of the available austenite for further steps of the heat treatments, affecting also the resulting mechanical properties. In this case, the cooling rate needed to avoid
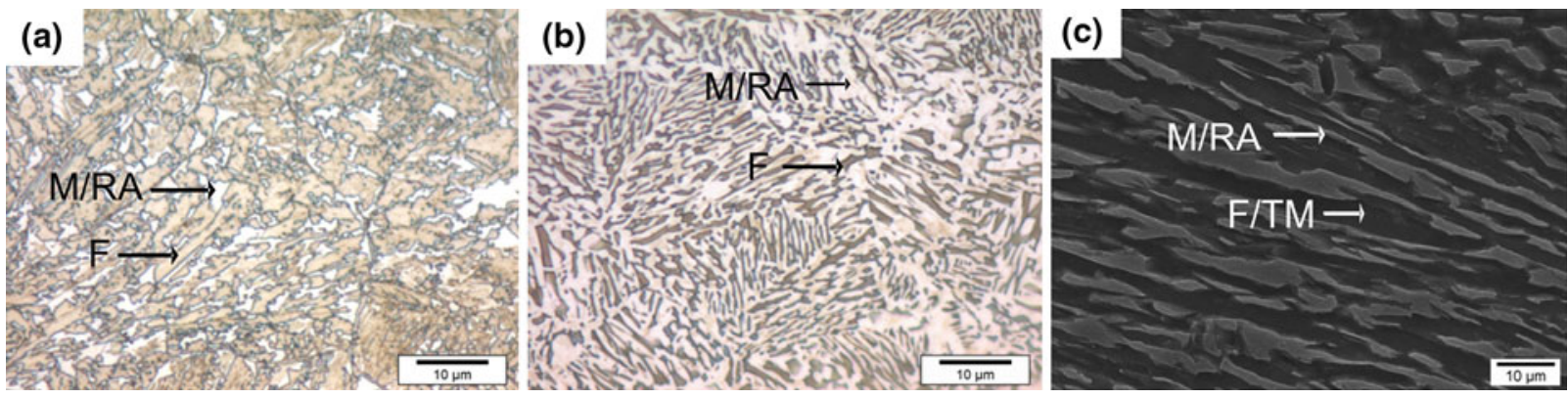

Fig. 1-Microstructure of a 0.2C-3.5Mn-1.5Si (wt pct) steel. (a) Initial microstructure (LePera etching). (b) Microstructure after partial austenitization at $1043 \mathrm{~K}\left(770{ }^{\circ} \mathrm{C}\right)$ for $600 \mathrm{~s}$ and further quench at $50 \mathrm{~K} / \mathrm{s}$ to room temperature (LePera etching). (c) Microstructure after partial austenitization at $1043 \mathrm{~K}\left(770{ }^{\circ} \mathrm{C}\right)$ for $600 \mathrm{~s}$, quenching to $513 \mathrm{~K}\left(240{ }^{\circ} \mathrm{C}\right)$ and partitioning at $623 \mathrm{~K}\left(350{ }^{\circ} \mathrm{C}\right)$ for $1000 \mathrm{~s}$ (nital 2 pct etching). M: martensite; RA: retained austenite; F: ferrite, and TM: tempered martensite.
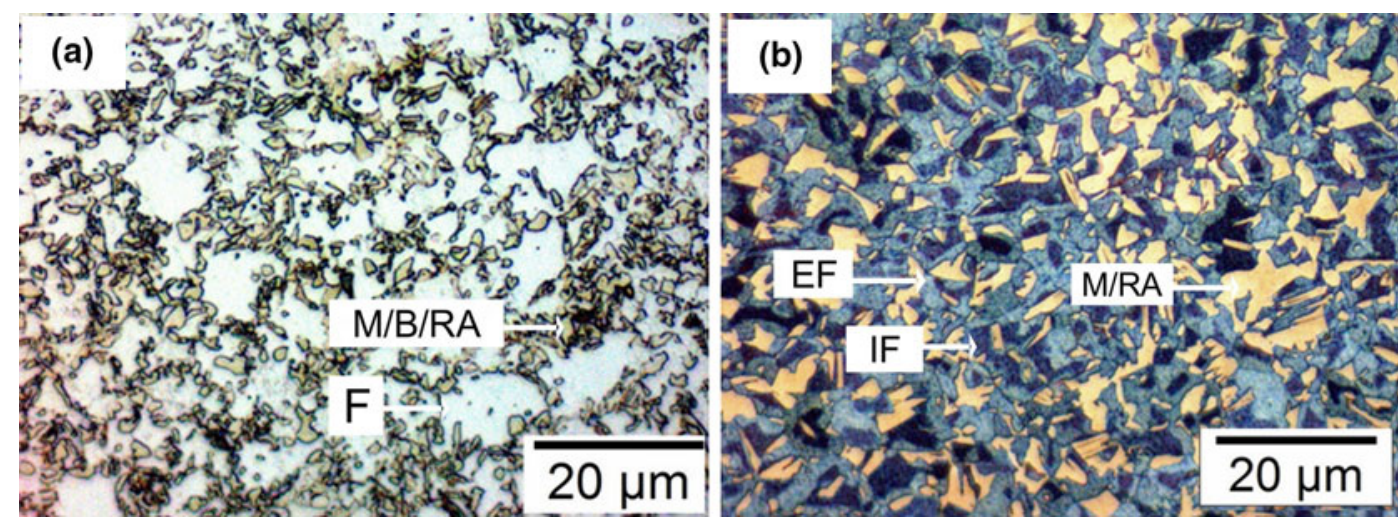

Fig. 2-Microstructure of a 0.19C-1.61Mn-0.35Si-1.10Al-0.09P (wt pct) steel. (a) Initial microstructure (nital 2 pct etching). (b) Microstructure after partial austenitization at $1173 \mathrm{~K}\left(900^{\circ} \mathrm{C}\right.$ ) for $600 \mathrm{~s}$ and quenching at $50 \mathrm{~K} / \mathrm{s}$ to room temperature (LePera etching). M: martensite; B: bainite; RA: retained austenite; IF: intercritical ferrite; and EF: epitaxial ferrite. 


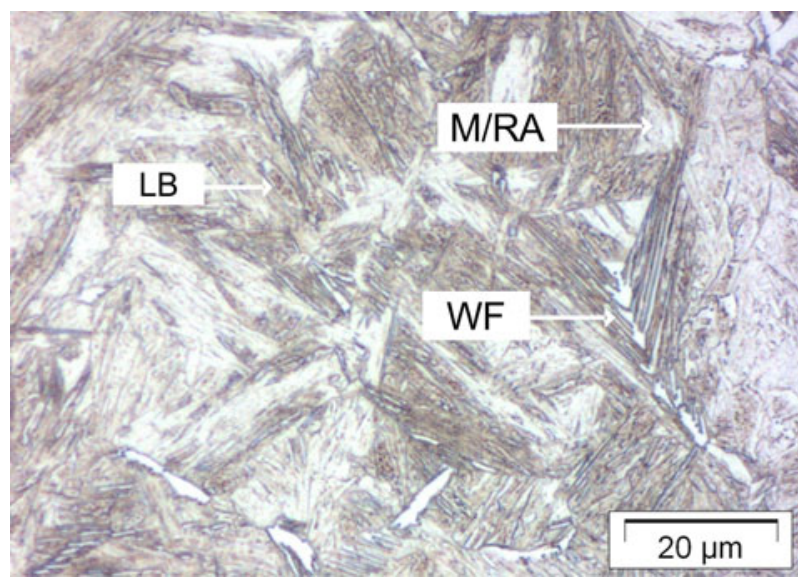

Fig. 3-Microstructure of a 0.19C-1.61 Mn-0.35Si-1.10Al-0.09P (wt pet) steel after full austenitization at $1373 \mathrm{~K}\left(1100{ }^{\circ} \mathrm{C}\right)$ for $300 \mathrm{~s}$ and quenching at $100 \mathrm{~K} / \mathrm{s}$ to room temperature (nital 2 pct etching).

the formation of these phases is higher than $100 \mathrm{~K} / \mathrm{s}$, which is too high to ensure an adequate control of the treatment at a determined quenching temperature between $M_{s}$ and $M_{f}$. These observations indicate that the chemistries of the alloys to be selected for application of the Q\&P process from full austenitization should contain austenite-stabilizing elements in order to inhibit the formation of these phases during cooling.

\section{MICROSTRUCTURAL CHANGES DURING QUENCHING AND PARTITIONING STEPS}

The quenching temperature determines the fraction of martensite that undergoes carbon partitioning to the neighboring austenite during the partitioning step. A quenching temperature closely above the $M_{f}$ temperature leads to the formation of an elevated fraction of martensite, which leaves a small fraction of austenite available for carbon enrichment. On the contrary, a quenching temperature closely below the $M_{s}$ temperature produces a small fraction of martensite, so the carbon available for partitioning might not be sufficient for the stabilization of the austenite. This trade-off leads to the determination of an optimal quenching temperature for a maximum in the volume fraction of retained austenite ${ }^{[12]}$ This optimal quenching temperature can be calculated based on the following assumptions: ${ }^{[12]}$ (1) there is full carbon partitioning from the martensite to the austenite at the end of the partitioning step, (2) martensite/austenite interface is fixed, and (3) any other phenomena such as bainite formation or carbide precipitation are precluded. The second and third assumptions imply that the austenite fraction does not change during partitioning.

Although these assumptions can lead to a good approximation of the optimal quenching temperature, the amount of carbon that actually partitions from the martensite to the austenite depends on the partitioning temperatures and times. Speer et al. ${ }^{[24,25]}$ and Hillert and Ågren ${ }^{[26,27]}$ proposed that the carbon partitioning from martensite to austenite is controlled by the so-called constrained carbon equilibrium, by which the diffusion of carbon from the martensite to the austenite ends when the chemical potential of carbon at the martensiteaustenite interface is the same in both phases, assuming a stationary interface. However, accepting these assumptions implies a difference in chemical potential of iron in martensite, and austenite at the interface is different throughout the process of carbon partitioning. This difference in the chemical potential of iron creates a driving force for the martensite/austenite interface movement toward full equilibrium. The martensite/ austenite interface migration alters the kinetics of carbon partitioning and the phase fractions. ${ }^{[28-30]}$ For example, Figure 4 shows one-dimensional (1-D) calculations of the kinetics of carbon partitioning at $723 \mathrm{~K}$ $\left(450{ }^{\circ} \mathrm{C}\right)$ of a binary $0.2 \mathrm{wt}$ pct $\mathrm{C}$ steel assuming that the widths of the filmy martensite and austenite are equal to $0.2 \mu \mathrm{m}$ and that the carbon concentration in every phase is the same at the beginning of the partitioning process. Figure 4(a) shows the carbon profiles in martensite and austenite assuming constrained carbon equilibrium (stationary interface), whereas Figures 4(b) and (c) show the kinetics of carbon partitioning assuming a mobile interface in which the activation energies for iron migration are 140 and $180 \mathrm{~kJ} / \mathrm{mol}$, respectively. Assuming constrained carbon equilibrium, the process of carbon partitioning is completed after approximately 10 seconds. However, when assuming a mobile interface, the results are quite different. An interface with an activation energy for iron migration equal to $140 \mathrm{~kJ} / \mathrm{mol}$ leads to the migration of the interface from the austenite to the martensite in the first stage, followed by the migration in the opposite direction. The entire process ends after around 100 seconds. Considering a more realistic case in which the martensite/austenite interface is less mobile $(180 \mathrm{~kJ} / \mathrm{mol})$, initially, the kinetics of carbon partitioning is quite close to the calculated kinetics assuming constrained carbon equilibrium, but later, significant migration of the martensite/austenite interface takes place until equilibrium conditions are reached. Clearly, the characteristics of a mobile martensite/austenite interface need to be studied further, since interface motion strongly affects the final microstructure after application of Q\&P treatments.

Assuming that all possible overlapping processes were successfully inhibited, the final microstructure after the Q\&P process after full austenitization is formed by martensite formed in the first quench that underwent carbon partitioning, martensite formed in the second quench, and retained austenite. The final volume fraction of phases after different heat treatments can be theoretically estimated by the application of the method developed by Clarke et al. ${ }^{[31]}$ Following that method, the volume fraction of martensite and austenite at the quenching step is related to the martensite and austenite grain sizes before the partitioning step, whereas the carbon-concentration gradient within the martensite and austenite grains determines the thermal stability of the austenite. In this way, the expected volume fraction of retained austenite after treatments with different partitioning times can be deduced. The possible martensiteaustenite interface mobility can also be included in the 


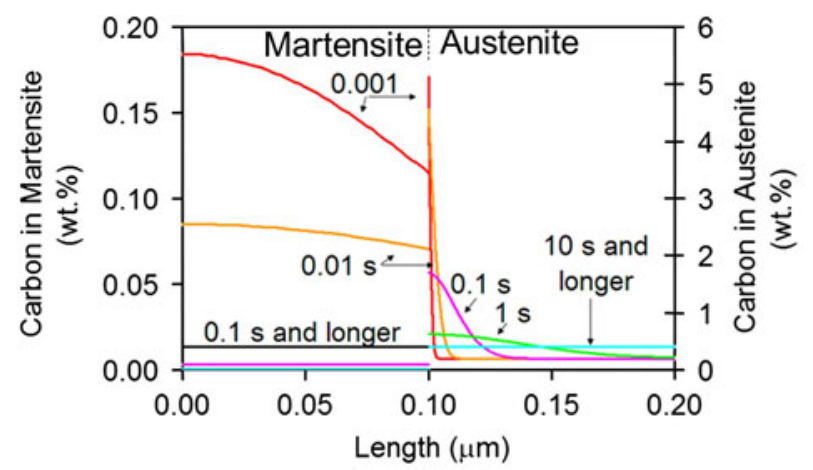

(a)

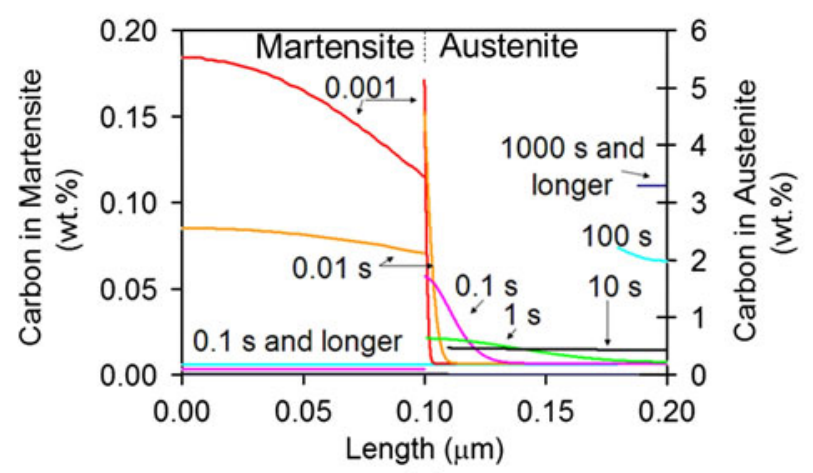

(c)

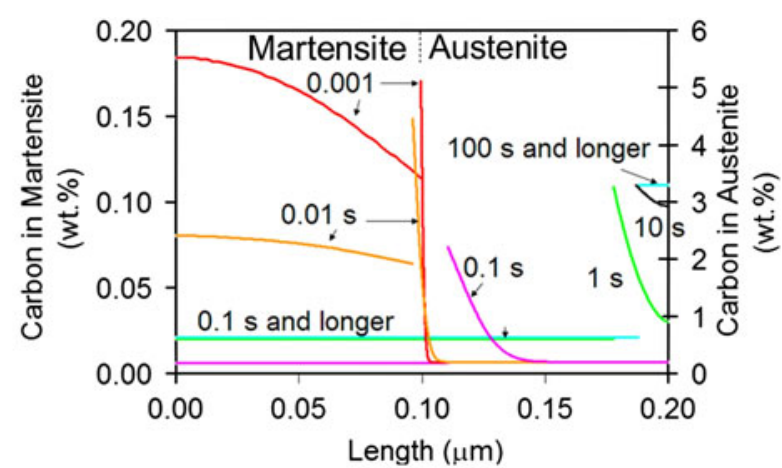

(b)

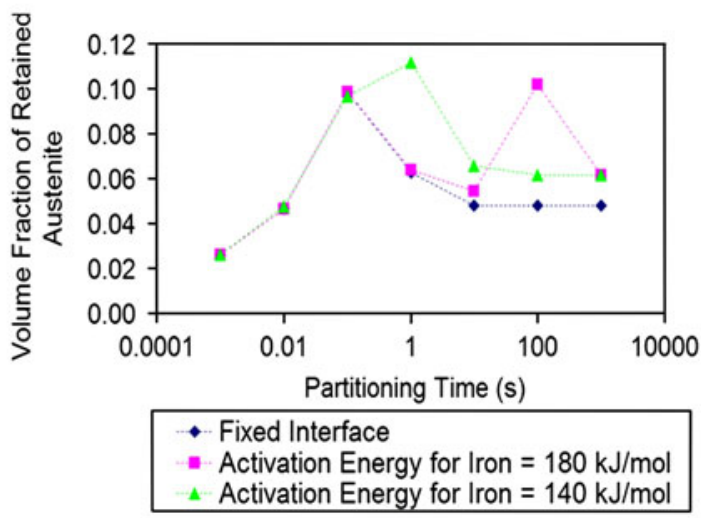

(d)

Fig. 4-1-D calculations of the kinetics of carbon partitioning assuming a $\mathrm{Fe}-0.2$ wt pct $\mathrm{C}$ binary system austenite and martensite thicknesses equal to $0.2 \mu \mathrm{m}$, and partitioning at $723 \mathrm{~K}\left(450{ }^{\circ} \mathrm{C}\right)$. (a) Fixed interface. $(b)$ Activation energy for iron migration equals $140 \mathrm{~kJ} / \mathrm{mol}$. (c) Activation energy for iron migration equal to $180 \mathrm{~kJ} / \mathrm{mol}$. (d) Estimation of the fractions of retained austenite at room temperature after partitioning at $723 \mathrm{~K}\left(450{ }^{\circ} \mathrm{C}\right)$ for different times and quenching to room temperature.

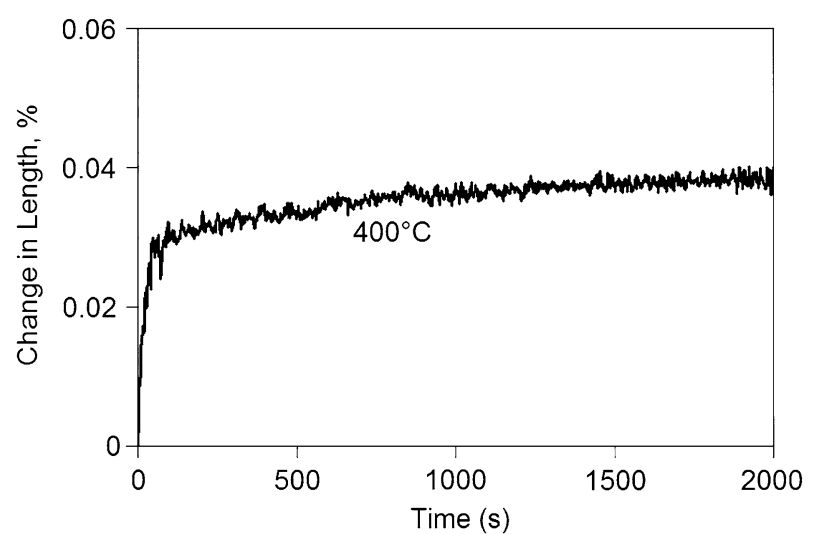

Fig. 5-Expansion observed during the partitioning step at $673 \mathrm{~K}$ $\left(400{ }^{\circ} \mathrm{C}\right.$ ) of a $0.2 \mathrm{C}-2.5 \mathrm{Mn}-1.5 \mathrm{Ni}-1 \mathrm{Cr}-1.5 \mathrm{Si}$ (wt pet) steel after full austenitization at $1173 \mathrm{~K}\left(900{ }^{\circ} \mathrm{C}\right)$ for $600 \mathrm{~s}$ and quenching to $548 \mathrm{~K}$ $\left(275^{\circ} \mathrm{C}\right)$.

calculations. ${ }^{[30]}$ Estimation of the expected volume fraction of retained austenite after the different partitioning conditions represented in Figures 4(a) through (c) is shown in Figure 4(d). Some interesting conclusions can be derived from this figure. For example, the expected volume fraction of retained austenite after partitioning at $723 \mathrm{~K}\left(450{ }^{\circ} \mathrm{C}\right)$ for 0.1 second or less (followed by quenching) is independent of the conditions assumed for the martensite/austenite interface, whereas the effect of the mobility is evident at longer times. Another interesting observation is the double maximum in the volume fraction of retained austenite in the case of calculations using an activation energy equal to $180 \mathrm{~kJ} /$ mol. This behavior might offer an explanation for the two peaks in the volume fraction of retained austenite experimentally observed during annealing by Matlock et al. ${ }^{[32]}$ These types of simulations are essential for the successful application of the Q\&P process.

Although martensite/austenite interface displacement is thermodynamically feasible, there is still no clear experimental evidence of its occurrence. Zhong et al..$^{[33]}$ observed curved martensite/austenite interfaces in an $0.2 \mathrm{C}-1.5 \mathrm{Si}-1.67 \mathrm{Mn}$ (wt pct) steel after full austenitization, quenching to $523 \mathrm{~K}\left(250^{\circ} \mathrm{C}\right)$ and partitioning at $753 \mathrm{~K}\left(480{ }^{\circ} \mathrm{C}\right)$ for 80 seconds, which were not observed after partitioning for 6 seconds. However, the exact relation of these curvatures with the original grain shape was not reported. On the other hand, several investigations showed an increase in the volume of the material during the partitioning step. ${ }^{[34,35]}$ However, this expansion can also be attributed to the formation of a new phase such as bainite, even in the case of partitioning temperatures below the $M_{s} \cdot{ }^{\left[{ }^{[6]}\right.}$ This possibility becomes more feasible since the presence of previously formed martensite can promote bainite formation. ${ }^{[37]}$

The occurrence of carbon partitioning from martensite to austenite in some steels is not necessarily 
accompanied by significant expansion of the material. Figure 5 shows the dilatometry signal detected in an $0.2 \mathrm{C}-2.5 \mathrm{Mn}-1.5 \mathrm{Ni}-1 \mathrm{Cr}-1.5 \mathrm{Si}$ (wt pct) steel after full austenitization at $1173 \mathrm{~K}\left(900^{\circ} \mathrm{C}\right)$ for 600 seconds, quenching to $548 \mathrm{~K}\left(275^{\circ} \mathrm{C}\right)$ and partitioning at $673 \mathrm{~K}$ $\left(400{ }^{\circ} \mathrm{C}\right)$ for 2000 seconds. The relative expansion detected is only 0.04 pct, which can be related with the formation of a volume fraction of bcc phase equal to only around 0.03 . This low expansion during the partitioning step indicates that neither significant interface migration nor significant bainite formation are occurring. The volume fraction and carbon content of retained austenite after further quenching was determined by X-ray diffraction, leading to 0.10 and $0.90 \mathrm{wt}$ pct, respectively. Given that no significant amount of bainite is formed, the austenite stabilization can only be due to carbon partitioning from martensite to austenite.

In the case of Q\&P steels in which the treatment starts with partial austenitization, the process of carbon partitioning from martensite to austenite can also occur through the ferrite that is present in the microstructure prior to the partitioning step. This option was revealed by phase field modeling simulations based on experimental observations on an $0.19 \mathrm{C}-1.61 \mathrm{Mn}-0.35 \mathrm{Si}-1.10 \mathrm{Al}-$ $0.09 \mathrm{P}$ (wt pct) steel. ${ }^{[38]}$ Simulations were done assuming partial austenitization at $1173 \mathrm{~K}\left(900{ }^{\circ} \mathrm{C}\right)$ for $600 \mathrm{sec}-$ onds, cooling at $50 \mathrm{~K} / \mathrm{s}$, quenching to $448 \mathrm{~K}\left(175^{\circ} \mathrm{C}\right)$, and partitioning at $623 \mathrm{~K}\left(350^{\circ} \mathrm{C}\right)$. Simulations show the formation of epitaxial ferrite during cooling, by growth of the ferrite present at the intercritical condition, which was also experimentally observed (as is also shown in Figure 2(b)). Since the formation of epitaxial ferrite during cooling leads to carbon enrichment of austenite grains in regions close to ferrite, the formation of martensite at the quenching step takes place in the carbon-depleted interior zones of the austenite grains. Figure 6(a) shows the simulated microstructure at the quenching temperature. Since it is not feasible to

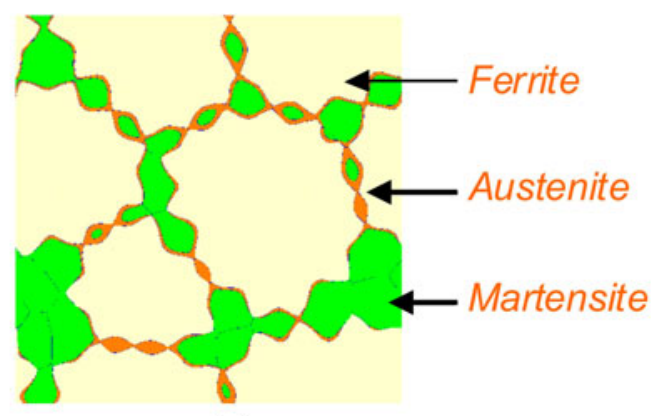

(a)
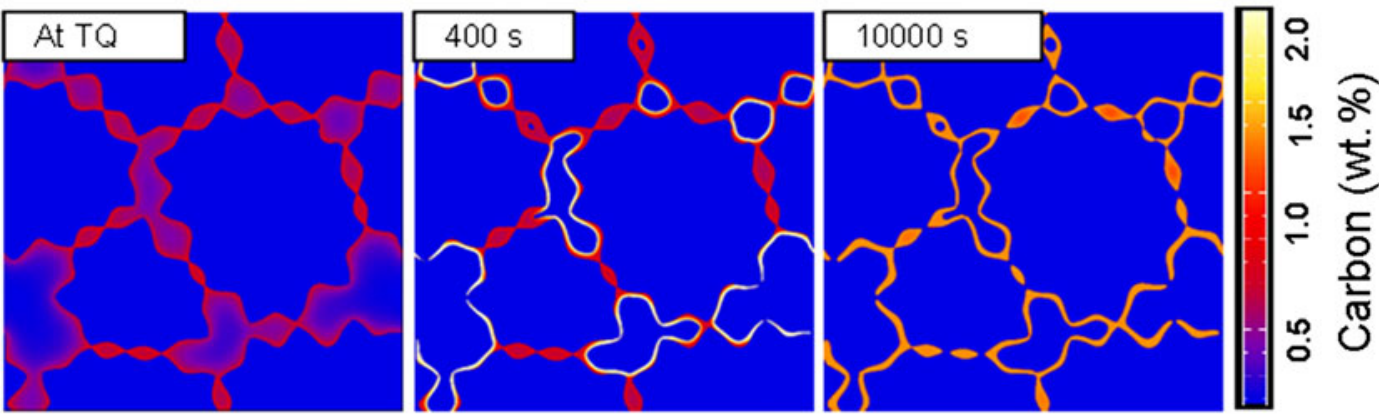

(b)
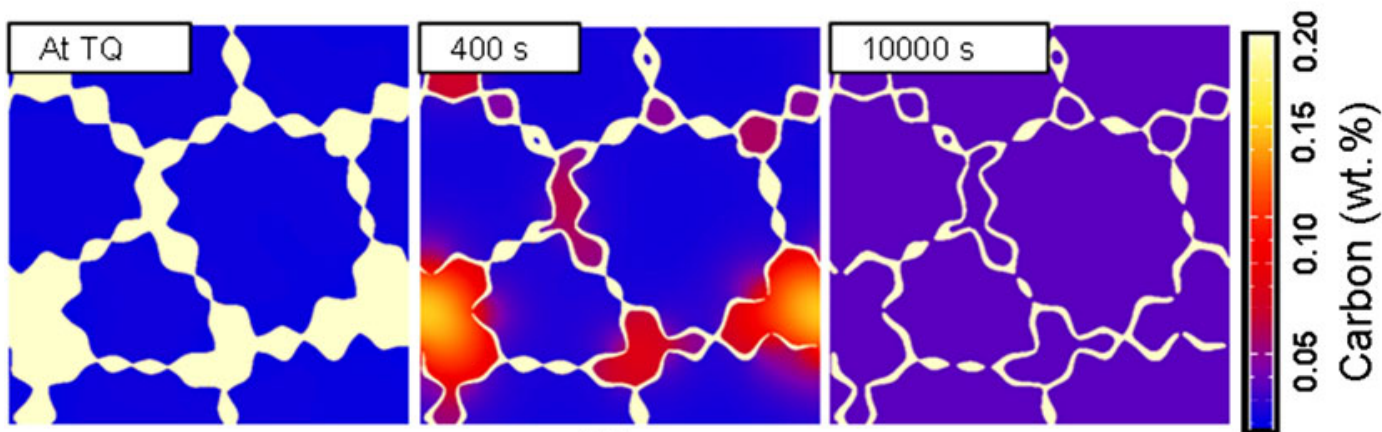

(c)

Fig. 6 - Simulated microstructure after partial austenitization at $1173 \mathrm{~K}\left(900{ }^{\circ} \mathrm{C}\right)$, quenching to $448 \mathrm{~K}\left(175{ }^{\circ} \mathrm{C}\right)$ at $100 \mathrm{~K} / \mathrm{s}$ and partitioning at $623 \mathrm{~K}\left(350^{\circ} \mathrm{C}\right)$ in a $0.19 \mathrm{C}-1.61 \mathrm{Mn}-0.35 \mathrm{Si}-1.10 \mathrm{Al}-0.09 \mathrm{P}$ (wt pct) steel. (a) Simulated microstructure at the quenching temperature. (b) and (c) Carbon concentration during partitioning with different carbon scales: (b) 0 to $2.0 \mathrm{wt}$ pet $\mathrm{C}$ showing direct carbon partitioning from martensite to austenite and (c) 0 to 0.2 wt pct $\mathrm{C}$ showing carbon partitioning from martensite to austenite through the ferrite. 
simulate at the length scale of the martensite, conglomerates of martensite laths are considered as martensitic grains in this study. Figures 6(b) and (c) show two diagrams displaying the distribution of carbon in the microstructure after partitioning at $623 \mathrm{~K}\left(350{ }^{\circ} \mathrm{C}\right)$ for different times. The difference between Figures 6(b) and (c) is the color scale used in the representation of carbon concentrations. Figure 6(b), with a wider scale ( 0 to $2.0 \mathrm{wt}$ pct $\mathrm{C}$ ), shows the direct partitioning of carbon from the martensite conglomerates to the neighboring austenite with increasing partitioning time. However, a smaller scale (0 to $0.2 \mathrm{wt}$ pct C) (Figure 6(c)) reveals that carbon partitioning from the martensite to the austenite can also occur through the ferrite. Simulations show that the last mechanism is possible, but it is seldom mentioned in the literature so far.

\section{SELECTION OF CHEMISTRIES AND TREATMENTS}

Chemistries for the application of the Q\&P process contain alloying elements inhibiting the formation of carbides, since they act as a sink of carbon that is then no longer available for partitioning to austenite. Up to date, silicon is the alloying element that has shown the highest success in this aspect, whereas other elements such as aluminum, which is effective at avoiding carbide precipitation in TRIP steels, have been shown to be less effective for Q\&P. ${ }^{[12,35]}$ In this case, the formation of ferrite, pearlite, or bainite during cooling or during the partitioning step is to be avoided; the chemical composition should also contain austenite-stabilizing elements to reduce the temperature window for bainite formation as well as to delay ferrite and bainite incubation times for the longest time possible. ${ }^{[9-11]}$ Otherwise, the formation of new phases during the quenching or partitioning step would reduce the amount of austenite available for stabilization. Alloying elements such as manganese and nickel have been proven effective in reaching those targets..$^{[9,11]}$ On the other hand, research is also in development regarding the possible combination of carbon partitioning from martensite to austenite and carbide-free bainite formation as an attractive method to contribute to the carbon enrichment of the austenite. In this case, the alloying content of the steels needed to reach the targeted microstructures can be considerably reduced.

Theoretical selection of optimum quenching temperatures requires previous knowledge of the martensite formation kinetics in the steel. Typically, martensite kinetics is described by the Koistinen and Marburger equation, ${ }^{[39]}$ for which recently a new effective approach has been published ${ }^{[40]}$ that takes into account the effect of alloying elements. Determination of the most adequate combination of partitioning temperature and time requires the application of kinetic models for carbon partitioning from martensite to austenite such as the ones mentioned in Section III. The partitioning time must be long enough to lead to considerable carbon partitioning, but also be restricted, since the risk of formation of carbides as a consequence of the martensite and austenite tempering also increases at longer times.

\section{CONCLUSIONS}

An overview of the microstructural changes during the application of the $\mathrm{Q} \& \mathrm{P}$ process in different steels was presented. The most important observations are summarized in the following points.

1. The initial microstructure of the steel strongly influences further microstructural changes and morphologies during the Q\&P process in the case of partial austenitization. The presence of a high fraction of initial martensite promotes the formation of filmlike Q\&P microstructures, whereas a predominant presence of allotriomorphic ferrite in the initial microstructure leads to polygonal Q\&P morphologies.

2. Chemistries for the application of the Q\&P process should contain alloying elements inhibiting the formation of carbides. The addition of austenitestabilizing elements to the steel can effectively reduce the formation of undesired phases such as epitaxial ferrite, bainite, and Widmanstätten ferrite.

3. Proposed models for the selection of Q\&P processing parameters demonstrated that martensite/ austenite interface dynamics strongly affects the kinetics of carbon partitioning and thus the development of the microstructure during the partitioning step. Phase field simulations showed that the process of carbon partitioning from martensite to austenite can occur through the ferrite.

\section{ACKNOWLEDGMENTS}

This research was carried out under Project No. M41.09246 in the framework of the Research Program of the Materials innovation institute M2i (www.m2i.nl). The support of this project by Tata Steel Europe RD\&T in IJmuiden is acknowledged. The authors express their gratitude to Mr. Y. Takahama for the phase field simulations and to Professor J.G. Speer and Dr. A.J. Clarke for fruitful discussions.

\section{OPEN ACCESS}

This article is distributed under the terms of the Creative Commons Attribution Noncommercial License which permits any noncommercial use, distribution, and reproduction in any medium, provided the original author(s) and source are credited.

\section{REFERENCES}

1. D.K. Matlock and J.G. Speer: Microstructure and Texture in Steels, A. Haldar, S. Suwas, and D. Bhattacharjee, eds., Springer, New York, NY, 2009, pp. 185-205.

2. J.G. Speer, A.M. Streicher, D.K. Matlock, F.C. Rizzo, and G. Krauss: Austenite Formation and Decomposition, E.B. Damm and M. Merwin, eds., TMS/ISS, Warrendale, PA, 2003, pp. 505-22.

3. M.J. Santofimia, L. Zhao, and J. Sietsma: Mater. Charact., 2008, vol. 59, pp. 1758-64.

4. M.J. Santofimia, L. Zhao, and J. Sietsma: Metall. Mater. Trans. A, 2009, vol. 40A, pp. 46-57. 
5. J.-W. Jin, S.H. Byun, S.B. Lee, S.I. Kim, C.S. Oh, N. Kang, and K.-M. Cho: Proc. Int. Conf. on New Developments in Advanced High-Strength Sheet Steels, Association of Iron and Steel Technology, Warrendale, PA, 2008, pp. 169-78.

6. S.J. Kim, H.S. Kim and B.C. De Cooman: Proc. Materials Science and Technology, MS and T, Detroit, MI, 2007, pp. 73-83.

7. A.M. Streicher, J.G. Speer, D.K. Matlock, and B.C. De Cooman: Proc. Int. Conf. on Advanced High Strength Sheet Steels for Automotive Applications, J.G. Speer, ed., AIST, Warrendale, PA, 2004, pp. 51-62.

8. N. Zhong, X.D. Wang, B.X. Huang, Y.H. Rong, and L. Wang: 3rd Int. Conf. on Advanced Structural Steels, Gyeongju, Korea, 2006, pp. 885-91.

9. M.J. Santofimia, T. Nguyen-Minh, L. Zhao, R. Petrov, I. Sabirov, and J. Sietsma: Mater. Sci. Eng. A, 2010, vol. 527A, pp. 6429-39.

10. H.Y. Li, X.W. Lu, W.J. Li, and X.J. Jin: Mater. Metall. Trans. A, 2010, vol. 41A, pp. 1284-1300.

11. A.R. Martins, F. Rizzo, D. Coelho, J.G. Speer, D. Matlock, K. He, and D. Edmonds: Int. Conf. Materials Science and Technology (MS\&T), Steel Processing, Product and Applications Symposium, Pittsburgh, PA, 2009.

12. J.G. Speer, F.C. Rizzo, D.K. Matlock, and D.V. Edmonds: Mater. Res., 2005, vol. 8, pp. 417-23.

13. J.S. Kirkaldy and E.A. Baganis: Metall. Trans. A, 1978, vol. 9A, pp. 495-501.

14. Y.-K. Lee and M.T. Lusk: Metall. Mater. Trans. A, 1999, vol. 30A, pp. 2325-30.

15. K.W. Andrews: J. Iron Steel lnst., 1965, vol. 203, pp. 721-27.

16. MTDATA Software, <http://mtdatasoftware.tech.officelive.com/ default.htm>.

17. THERMO-CALC Software, <http://www.thermocalc.se/>.

18. F.S. LePera: Metallography, 1979, vol. 12, pp. 263-68.

19. M.J. Santofimia, L. Zhao, R. Petrov, and J. Sietsma: Mater. Charact., 2008, vol. 59, pp. 1758-64.

20. M.J. Santofimia, C. Kwakernaak, W.G. Sloof, L. Zhao, and J. Sietsma: Mater. Charact., 2010, vol. 61, pp. 937-42.

21. M. Erdogan and R. Priestner: Mater. Sci. Technol., 1999, vol. 15, pp. $1273-84$.
22. G.S. Huppi, D.K. Matlock, and G. Krauss: Scripta Metall., 1980, vol. 14, pp. 1239-43.

23. E. Ahmad, M. Sarwar, T. Manzoor, and N.J. Hussain: J. Mater. Sci., 2006, vol. 41, pp. 5417-23.

24. J.G. Speer, D.K. Matlock, B.C. De Cooman, and J.G. Schroth: Acta Mater., 2003, vol. 51, pp. 2611-22.

25. J.G. Speer, D.K. Matlock, B.C. De Cooman, and J.G. Schroth: Scripta Mater., 2005, vol. 52, pp. 83-85.

26. M. Hillert and J. Ågren: Scripta Mater., 2004, vol. 50, pp. 697-99.

27. M. Hillert and J. Aggren: Scripta Mater., 2005, vol. 52, pp. 87-88.

28. J.G. Speer, R.E. Hackenberg, B.C. De Cooman, and D.K. Matlock: Philos. Mag. Lett., 2007, vol. 87, pp. 379-82.

29. M.J. Santofimia, L. Zhao, and J. Sietsma: Scripta Mater., 2008, vol. 59, pp. 159-62.

30. M.J. Santofimia, J.G. Speer, A.J. Clarke, L. Zhao, and J. Sietsma: Acta Mater., 2009, vol. 57, pp. 4548-57.

31. A.J. Clarke, J.G. Speer, D.K. Matlock, F.C. Rizzo, D.V. Edmonds, and M.J. Santofimia: Scripta Mater., 2009, vol. 61, pp. 149-52.

32. D.K. Matlock, V.E. Bräutigam, and J.G. Speer: Mater. Sci. Forum, 2003, vols. 426-432, pp. 1089-94.

33. N. Zhong, X. Wang, Y. Rong, and L. Wang: J. Mater. Sci. Technol., 2006, vol. 22, pp. 751-54.

34. D.H. Kim, J.G. Speer, H.S. Kim, and B.C. De Cooman: Metall. Mater. Trans. A, 2009, vol. 40A, pp. 2048-60.

35. E. De Moor, J. Penning, C. Fojer, A.J. Clarke, and J.G. Speer: Int. Conf. New Developments in Advanced High-Strength Sheet Steels, Orlando, FL, 2008, pp. 199-207.

36. S.M.C. van Bohemen, M.J. Santofimia, and J. Sietsma: Scripta Mater., 2008, vol. 58, pp. 488-91.

37. H. Kawata, K. Hayashi, N. Sugiura, N. Yoshinaga, and M. Takahashi: Mater. Sci. Forum, 2010, vols. 638-642, pp. 3307-12.

38. M.J. Santofimia, L. Zhao, Y. Takahama, and J. Sietsma: Mater. Sci. Forum., 2010, vols. 638-642, pp. 3485-90.

39. D.P. Koistinen and R.E. Marburger: Acta Metall., 1959, vol. 7, pp. 59-60.

40. S.M.C. van Bohemen and J. Sietsma: Metall. Mater. Trans. A, 2009, vol. 40A, pp. 1059-68. 